\title{
Restoration of Urban Water Commons: Navigating Social-Ecological Fault Lines and Inequities ${ }^{\circ}$
}

\author{
Amrita Sen, Hita Unnikrishnan and Harini Nagendra
}

\begin{abstract}
The networked tank/lake system of Bengaluru has been created by human intervention, with a documented history as far back as the 9th century C.E. The construction and maintenance of the tanks was overseen by local chieftains, and supported by local communities, further managed by caste-based and gender-based systems of manual labor. With urban expansion, the lakes lost their importance as the primary sources of water, leading to large scale degradation. Land-use transformations impacted the socio-ecological commons landscape, exacerbating marginalization in nature-dependent communities such as grazers and fishers due to loss of livelihoods. State initiatives coupled with community interventions helped in revival of some lakes in the past decade, though others remain severely degraded. Privileged and underprivileged caste groups describe a very different picture of the past, demonstrating rather divergent perspectives on the way in which urbanization and lake revival has impacted their lives. Based on a case study of selected lakes in Bengaluru, we establish how social inclusions and exclusions are manifested through decision making on lake management. We also seek to understand how these hierarchies have changed in response to urbanization, with aspirations towards a rhetoric of restoration, but a focus on urban greening and recreational aesthetics in practice. The impacts of urban transition and lake revival are shaped by differing power relationships manifested within the caste hierarchy.
\end{abstract}

Keywords: commons, community, lake management, urban India

\section{\$) Restoration Recap (\&)}

- Inclusive ecological restoration practices in urban India can comprehensively benefit communities and ecosystems, if they go beyond rhetoric to practice.

- Functioning urban ecosystems provided a range of interconnected social, physical, and ecological benefits for different socio-economic classes in a city.

We envision that this lake when restored will be a place that is both beautiful and will foster a sense of community in the neighbourhood. It will be a place where birds thrive and where people can identify with. It will have fountains, lights, and a beautiful themed garden with mostly native plants. There will also be a place for children to play. The

2 This open access article is distributed under the terms of the CC-BYNC-ND license (http://creativecommons.org/licenses/by-nc-nd/3.0) and is freely available online at: http://er.uwpress.org

Ecological Restoration Vol. 39, Nos. 1-2, 2021

ISSN 1522-4740 E-ISSN 1543-4079

(O)2021 by the Board of Regents of the University of Wisconsin System.
- Discriminatory urbanization and urban ecological revival without sufficient attention to restoration can manifest in wide-ranging social and ecological consequences. 
which a mere aestheticization might undermine provisioning services supporting specific marginal groups. In several cases, a technical aestheticized focus on urban greening has undermined local community livelihoods and, in-turn, long term sustainability goals of achieving equity and social justice (Fox and Cundill 2018). A prevalence of objectives such as landscaping, creating fountains, and providing recreational play areas misses out on an imagination of the lake as a place for provisioning and utilitarian needs of farmers, fishermen, or urban foragers. Related to this is the imagination of a middle class, relatively homogenous urban community, possessing shared aspirations and interests which can be motivated to coproduce or undertake stewardship of the resource.

As idyllic as these visions are, urban communities in the Global South are far more heterogeneous than these narratives indicate. Restoration and management of urban water commons in these spaces require engagement with these ideas of complexity, disparity, inequity, and power imbalance. However, what passes as ecological restoration projects in official documents is fundamentally oriented towards the creation of enclosed, upper-class spaces, overriding concerns over collective justice. In this paper, we argue that ecological commons in cities can have profound values for long-term human wellbeing of numerous communities-specifically urban marginals, whose stakes and interests need to be recognized while designing nature restoration plans. But in most cases, provisioning services supporting communities are ignored and delegitimized and many of these practices draw on culturally and institutionally embedded systems of social inequalities around the management of commons. We provide a deep-dive into the networked lake commons of the south Indian city of Bangalore to demonstrate inequities, heterogeneities, and contestations that have existed around lake spaces for centuries. We explain how many of these structured inequities manifest themselves in contemporary environmental thinking, ultimately organizing itself into elitist greening projects across cities, that are framed as restoration, yet largely ignoring social-cultural and ecological costs.

Ecological restoration is critical for increasing adaptive capacities of cities by combating local pollution levels, carbon sequestration, climate regulation, along with provisioning a range of cultural and non-monetary services (Elmqvist et al. 2015, McDonald et al. 2016, Clarkson and Kirby 2016, Johnson and Handel 2019). Communities, despite being from different locations, can feature prominently in urban biodiversity restoration, since human values, wellbeing, culture and socio-economic activities are integrally linked to nature around them (Standish et al. 2013, Sen and Nagendra 2020a). As Gobster (2007) points out, human values should be considered key elements for successful ecological restoration processes, considering the role that they play in balancing nature conservation and environmental equity. Community participation, recognition of local knowledge and institutions, supporting landscape dependent livelihoods, and understanding restoration processes that can recognize and accommodate local values and needs should all be key strategies linked to restoration (Fox and Cundill 2018).

Yet in practice, in many Indian cities the emphasis on restoration remains on paper. Projects take on an approach of urban greening via landscape redesign, with a dominant goal of providing recreational opportunities for certain civic groups, especially in upscale neighbourhoods. Our paper aims to advance an understanding of the gap between aspirations towards restoration, and the reality of such project designs on the ground in urban India. We describe how issues of inclusion and social and environmental justice are omitted because of the lack of attention to the requirements of socially and ecologically embedded approaches to restoration. Drawing on extensive long-term research around networked lake commons of the south Indian city of Bangalore, we demonstrate prominent fault-lines on how social and cultural inequities have continued into the present day, shaping discourses of lake restoration and on-ground practices of urban greening, posing serious implications for the balancing of ideas of social justice with aspirations of sustainable cities. Finally, we reflect upon ways in which restoration of urban water commons may be more reflective of imperatives of ecology and equity.

\section{Methodology and Field Areas}

Our chosen methods involve a mix of exploratory review and empirical fieldwork. For the review, we have relied on literature search, enabling us to pay attention to urban transformations, with a distinctive focus on Bengaluru as a city. This exploratory review has helped us capture structurally embedded elements of power and exclusion in varying degrees, which are constitutive of current lake revival efforts and their role in entrenching expressions of informality upon urban peripheral communities. For the empirical part, we used semi structured and oral history interviews, conducted between 2013 and 2018 with residents living around several lakes in Bangalore, coupled with archival data on lake management in the past. The lakes that have been included for the purpose of this paper are Sampangi and Dharmambudhi Lakes, for understanding the patterns of "restoration" that these lakes have been subjected to over decades; and Sawle Kere and Bellandur Lakes for understanding more recent challenges (Figure 1). Archival data had immense explanatory capacity for shaping the findings of this research, since a reasonably large amount of information could be collected from public records about temporal shifts in beliefs and practices associated with management of the lakes as critical community commons. Qualitative interviews-primarily oral histories-helped in revisiting interesting historiographies and collective remembrances from multiple actors, memories 


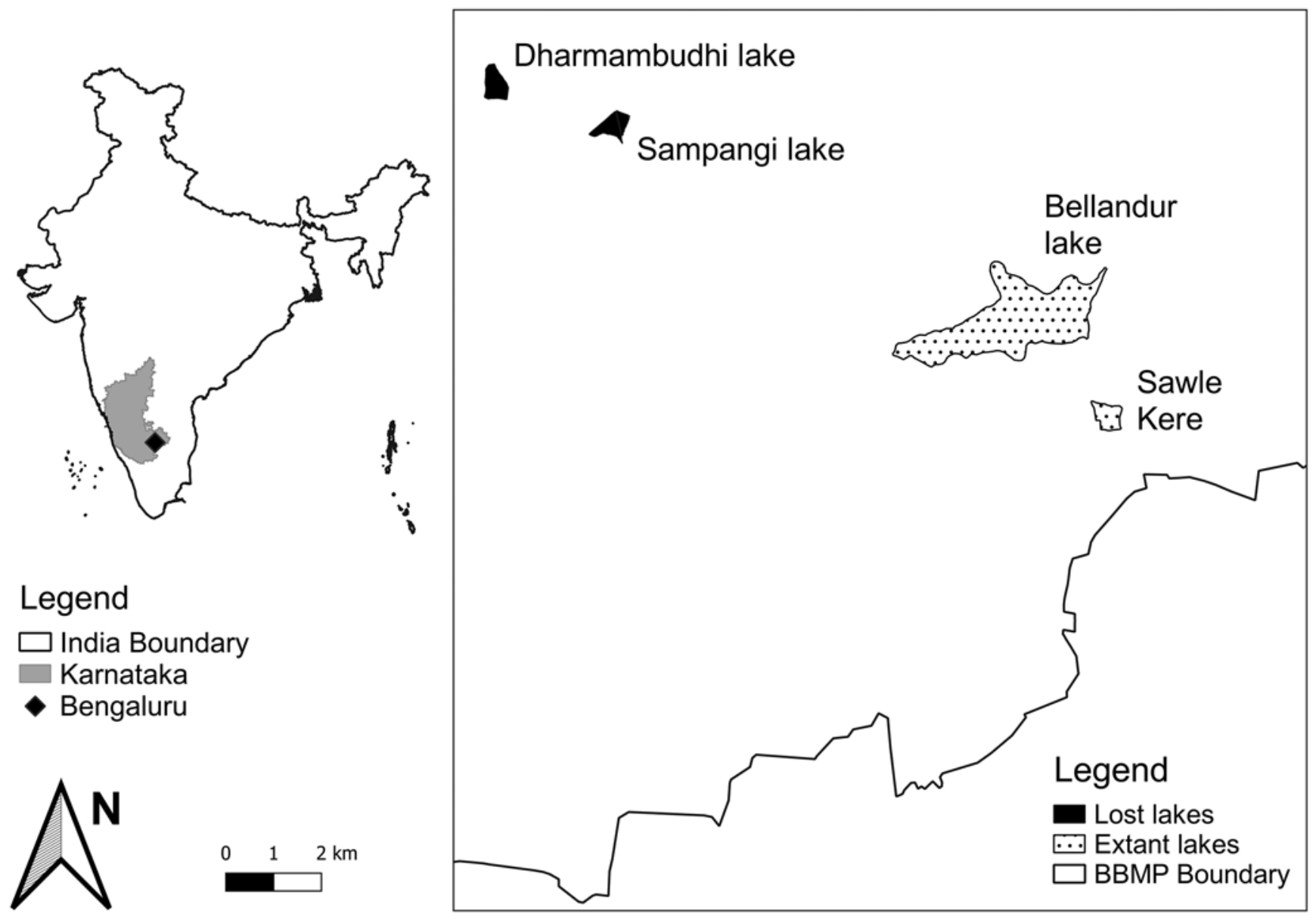

Figure 1: (inset) Map showing the city of Bengaluru as it is positioned within Karnataka, India; (main) Map showing the four study sites: Sampangi lake (lost), Dharmambudhi lake (lost), Bellandur lake (extant), and Sawle Kere (extant) as they are positioned within the partial jurisdictional boundary of the city's nodal agency (BBMP).

of the lakes, and governing institutions and social conflicts. Semi-structured interviews with stakeholders were critical in understanding the challenges of access to lakes in contemporary cities. We have used a descriptive frame of analysis to capture and communicate diverse social dimensions of an inherently iniquitous process of urban lake revival, officially characterized as lake restoration.

\section{Networked Lakes, Fractured Communities: An Exploratory Framework}

Indian urban areas and their core, subcentres, and peripheries have substantially expanded in the last couple of decades, transforming much of the rural-agrarian hinterland landscapes into built spaces. Several studies have pointed to the current crises as well as longstanding effects of urban transformations, as specifically affecting the fringe population that was predominantly agrarian. According to Appadurai (2001: 25), such transformations have made blatantly visible contradictions between "high concentrations of wealth and even higher concentrations of poverty and disenfranchisement" in many megacities of India.
One reason commonly cited for physical and social disparities of this kind is the rapid usurpation of agriculturally productive community lands in the peripheral rural areas towards urban land-use purposes and technological infrastructures. Multinational franchises, high-rises and supermarkets, exquisite shopping malls attracting well-off urban shoppers, fitness centres, multi-speciality clinics and the like are the essentials of the urban elite, as well as common facilitators of swift transformations towards world-class cities. However, much of the spectacular city life and strategies of urban planning and development, as de Certeau (1984: 93MC) pointed out, demonstrates a "simulacrum", whereby everyday practices of the ordinary people are best examples of resistance to the established structures of power. The predominant agenda today of making cities "global" rests on cumulative capitalist capacities to reinforce power, control financial instruments and consolidate place-bound material and human resources (Sassen 2000). We find a similar process of recent urban greening efforts in cities being gradually integrated within technocratic and profit-driven endeavours of capitalist growth processes, with an environmental ideology being 
focused on aestheticizing nature through biophysical transformations-creation of manicured parks with exotic plantations, gated green spaces, rooftop gardens and other built features (Kaika 2005, Gibas and Boumová 2019). None of these agendas address social-ecological associations and rights to justice since they act to disenfranchise marginal groups by severing critical provisioning environmental resources (Baviskar 2018).

Functional diversifications, formal legal and administrative systems and high-end technological developments are dominant forces characterizing life in a global city. Everyday lives in megacities are essentially impersonal, where erstwhile communal bonds tend to get weakened and replaced by transitory relationships. Classical sociological thinkers, like Louis Wirth (1938), commonly associated urbanism of this sort as inexorable-a dismal way of life, with large scale segmentation of human relations, anonymity and superficiality replacing personal relations and customary community-based institutions. Others have explored the expansive blanketed effects of urbanization on fringe villages of a city-ways in which consumerism, market and occupational diversifications are replacing traditional economy and life-worlds in rural areas situated along urban borders (Rao 1970, Jaysawal and Saha 2014, Denis and Zerah 2017, Sen and Nagendra 2020b). In sum, interfaces of urbanization on the lives of disadvantaged communities are complex and frequently disenfranchising.

Urbanization experiences of former village communities in Bengaluru has been discussed much on similar lines, with urban sprawl and increase in population inducing tangible inequities in terms of access to land, basic infrastructure and livelihoods (Thippaiah 2009, Nagendra 2016a, Nagendra 2016b, Mundoli et al. 2015). Specific studies on poverty in Bengaluru have demonstrated how governance processes systemically disenfranchised the poor in the city, through demolition of low-income settlements, resettlement, and increase in land prices (Benjamin 2000). The urban renewal of Bengaluru, driven by investments made at the national and state level, which was propelled by the drive to make the city "globally competitive" as an information technology hub, largely excluded the city's marginals, who continue to live with minimal infrastructure and basic amenities (Benjamin 2000, Srinivas 2002, Unnikrishnan and Nagendra 2018, Unnikrishnan et al. 2020). A number of studies have also pointed out the ecological impacts of rapid urbanization and the exploitation of urban ecological commons like lakes and rivers, in dislodging Bengaluru's marginal populations (D'Souza and Nagendra 2011, Sudhira and Nagendra 2013, Unnikrishnan et al. 2016).

The city of Bangalore by virtue of its geographical position within a rain shadow and its conspicuous lack of a major river is naturally prone to aridity (Sudhira et al. 2007). It has occupied a prominent position in southern India for several centuries beginning with the city's formal founding in 1536 by a local chieftain. Settlements have however (unusually for a water scarce city) flourished in the region since prehistoric times (Annaswamy 2003). The propensity of the terrain to remain scarce of water was recognized by these early settlements resulting in the creation of an intricate, engineered system of water tanks, connected by means of channels, and cascading across the elevation gradient characteristic to the city (Unnikrishnan et al. 2017). Seasonally replenished water in these lakes flowed from one lake into the other across the gradient, creating a system by which water was circulated across the landscape and made available for agrarian livelihoods. Together with open wells that tapped into shallow aquifers recharged by the lake, a measure of water security for the city was achieved, allowing a number of settlements to flourish (Nagendra 2016). This system of water supply was in operation until the mid-nineteenth century when the city began to receive piped water from other distant sources (Unnikrishnan et al. 2020). In a sense therefore this act of engineering the waterscape enabled the creation of liveable spaces in formerly harsh terrain (Unnikrishnan and Nagendra 2020).

Given its importance in enabling livelihoods and daily lifestyles, the constructed network of reservoirs was influenced deeply by social hierarchies as well as cultural practices, thereby influencing how the resource was managed and appropriated (Mosse 1997). Even though this system of interconnected lakes was reflective of deeper engagement with local ecologies, it built on and was sustained by social structures of deep inequity (Shah 2012). This inequity became visible when one scrutinizes the institutional and cultural traditions associated with lake management in Bangalore since precolonial times. Marginalized castes speak about extreme inequities imposed by hierarchies and ostracisms, that shaped the use and management of lake commons. These hierarchies impacted livelihoods, social interactions, and physical associations (Sen and Nagendra 2020b).

An important role in the institutional management of water supply by tanks was ascribed to village water men ("neerganti") (Shah 2003). They bore the responsibility of measuring water levels within the reservoir and allocating sufficient water to agricultural fields by manning the sluice gates responsible for controlling water outflow from the tanks (Gurakkal 1986, Shah 2003). As important as this role was towards sustaining the agrarian economy, the "neerganti" community belonged to a more marginalized caste, and subsisted through receiving shares from the local harvests that they supported (Shah 2003). The construction of tanks was undertaken by a caste group, the "Voddas" who often put in significant labor, made difficult by the provision of only basic equipment such as crowbars, baskets, or rakes (Shah 2003). Once built however, local elites from higher caste groups exerted control over the waterscape, retaining power to allocate water and land to people of their choice (Rice 1897). Local folk songs, passed 
down through generations, reference the construction of a new tank-almost always describing the sacrifice of women and children to appease local deities (Shah 2012). It was believed that the sacrifice of women and newborns before or during the construction of a reservoir would appease the wrath of local deities, while at the same time ensuring plentiful supply of water and therefore bountiful harvests from fields that were irrigated by the tank (Shah 2003). In a sense therefore, human sacrifice was also an opportunity for local elites to exert their ownership over the resource through exploiting the cultural belief systems of the time.

The practices of precolonial lake management were not therefore, as is sometimes claimed, those of a unified community working together in harmony to manage their local resource systems. Instead, they are reflective of a deeply fractured, iniquitous community, that sustained itself over time through internalized social and cultural hierarches, while yet demonstrating mastery of local ecologies that enabled the creation of water security within the region. As we demonstrate below, these hierarchies have been carried into modern times, perpetuating some forms of inequity while creating other newer forms of marginalization, influencing and in turn influenced by the design and maintenance of these systems.

\section{Historical and Social-Ecological Fault Lines}

The city of Bangalore came under British colonial rule after the defeat of the local ruler Tipu Sultan in CE 1799 (Sudhira et al. 2007). This change in governance brought with it gradual, yet dramatic transformations in ideologies and practices surrounding urban water management. Bangalore, by virtue of its high elevation and mild weather was particularly attractive for European settlers. Large numbers of Europeans began to call the city their home, and this further attracted native migrants from other parts of the country in search of labor and better living conditions. This increased population also meant an increased demand for essential resources such as water, exerting unprecedented pressure upon the existing system of networked tanks which characterized water supply to the city. This increased demand for water later coincided with the advent of electricity, making possible alternative solutions to meet the new demand-solutions that involved pumping water across increasingly long distances directly into the homes of people. The new networked piped infrastructure began to render the older tank system obsolete, which then led to their degradation and conversion into other built structures over time (Unnikrishnan and Nagendra 2020).

Changes in physical infrastructure were concomitant with changing ideas and discourses around water supply. European experiences with epidemics like plague and cholera, both in their homeland as well as in the various colonies they established, created, reproduced, and perpetuated new discourses of the sanitary city (Melosi 2008, Unnikrishnan, et al. 2020). These discourses established the supremacy of western technologies (such as closed, networked, and piped water supply systems) over indigenous ones-the tanks. Ideas of racially segregating populations for continued health and safety of the British took firm root (Castán Broto 2019), resulting in the establishment of two distinct and dually governed zones within the city by 1881 . The first zone was the anglicized Cantonment (governed entirely by the British) and the other was the native "Pete", comprising of native agricultural and industrial hubs and governed by the native rulers of Mysore (Unnikrishnan et al. 2016). Power was largely concentrated in British hands. Every effort was made to keep activities within these zones as separate as possible. Water constituted a contested resource claimed by inhabitants of both the zones, creating inequities because of the power hierarchies between different groups of residents.

An informative example of contestations over water is the transformation of the centrally located Sampangi lake into the city's prominent sports stadium. Located on the border of the City and the Cantonment, the lake was important to sustain the lifestyles and livelihoods of several groups of people who lived around it. Water from the lake was (until the advent of piped water) used to meet domestic water supply in the vicinity. The lake supported a substantial population of native horticulturists, farmers, weavers, and fishermen (Unnikrishnan et al. 2016). The establishment of the British Cantonment and the arrival of piped water into the region influenced changes in dominant perceptions surrounding the utility of the resource. While the lake continued to be an important enabler of water dependent livelihoods, it began to be seen as a nuisance to the lakeside bungalows and educational institutions that had by then been established around the lake. Petitions were filed by British residents asking the Government to reduce the level of water in the lake to prevent flooding. Contrarily, native horticulturalists filed petitions asking for increased water supply from the lake to fulfil their needs for irrigational water. Valued as a recreational area, restrictions began to be imposed upon digging wells and brick manufacture, and on livelihoods such as fishing that were deemed unsightly (Unnikrishnan et al. 2016). Part of the lake was drained to make way for a polo ground. As one of our interviewees, the son of a former horticulturist recalled,

In the early 1900s, we were here. We were growing flowers around the lake. There were a lot of fishermen too. All of a sudden there were restrictions to our movement. British guards in coloured uniform began patrolling the banks of the lake-they would punish anyone who fished or grazed cattle in the lake. People were using the lake to walk in the evenings, as a recreational spot. We had no place there. 
A fixation with aesthetics and recreation continued to gain prominence, prompting the migration of native populations out of the area or forcing them to take up alternate occupations. The lake began to be disused and polluted, eventually being drained to give way to an open field and playground, where a sports stadium was eventually constructed by 1945 . Inequities were manifested through the denial of legitimacy to livelihood-based dependencies built around the social-ecological system in ways that changed the lifestyles of local populations dramatically. As a local community male elder told us,

As the lake began to be used more by these uniformed guards, life became increasingly difficult for us. We found it very hard to cultivate our crops and so sold the land at throwaway prices. My family then started the business of delivering firewood to local houses-but it was a very time intensive and laborious process. We would wake up at 3:00 AM, go to the market, buy several logs of wood and bring it back home. Once home, all of us brothers would chop the logs into smaller sizes, create bundles of them and then sell it to our neighbours. Even then we were short of money. We then moved to real estate. We built more floors above our house and put them up for rent-that is our family's income now. It gives us money, but I long to see the days when we did not have to depend on a shop to give us our food-we would grow our own food and that has been lost to us.

At the same time, internal caste dynamics continue to be reproduced in subtle ways around the landscape. Former "neergantis" refuse to be identified as such stating that the only thing the identity brings with it is more marginalization. In the words of one of our male interviewees,

In those days being a "neerganti" was our occupation. We were proud of it because it gave us our food. Yes, people would treat us as untouchables, but we knew that without us there would be no fields, no food, and no tank. Today what is there for us? Just the fact that we belong to a lower caste. I don't want to be associated with that stigma and so I do not identify myself as a "neerganti" in most public interactions.

The landless may have been especially affected by socialecological transformations in the landscape, as is often seen. As one of our male interviewees added, in a presumed reference to bonded labor of the past,

The community that lived here consisted of poor working classes who were owned by a few rich people. These rich people lived elsewhere. When the tank was filled up, the workers were sold to new owners and they migrated to other areas.
This story is not unique to Sampangi lake. The transformation of several water bodies in the city tell similar tales of exclusion and vulnerability. The transformation of Dharmambudhi lake into Bengaluru's central bus station too is a testimony of how dominant colonial discourses of sanitation and technological superiority rendered the lake separate from urban life, creating opportunity to repurpose and transform it into another form of public infrastructure. This at the cost of impacting local livelihoods and lifestyles that were dependent upon the lake and whose visions of resource utility were different, but which held less sway over planning discourses of the time (Unnikrishnan and Nagendra 2020). Such urban redesign, without accounting for the magnitude of social effects that they entail, does not merely lead to inequities, but has collateral consequences on the sustainability of cities. In the next section of this paper, we show how these inequities have translated into lake revival, management and planning to the present day.

\section{Deepening Fault Lines in Contemporary Times}

Colonial ideas of prioritizing recreation and aesthetics did not die out with the creation of the modern independent state of India. Rather, these ideas have continued to dominate discourses of lake rejuvenation, further creating newer forms of inequity. Beginning in the 1980s, fuelled by concerns over the state of the city's rapidly declining tanks as well as their widespread pollution, several state and community led activities have aimed at restoring or rejuvenating the city's water bodies. Several lakes in Bengaluru have now been converted into fenced public spaces, with jogging trails, manicured gardens, outdoor gyms, benches to sit, and children's play areas. Many of these projects have unfortunately been driven by engineers and bureaucrats, with limited inputs from wealthy and middle-class local residents, and little or no consideration of the social-ecological heterogeneity that characterizes community dependence, especially that of low-income communities, on lakes. For instance, the project plans for most lakes include a sizeable budget for expensive ornamental gardens landscaped with exotic flowering species, rather than native, fruit-bearing trees and edible greens that are widely used by most local residents. Jogging and walking paths take over a sizeable chunk of the waterspread area of lakes. Grazing, subsistence fishing, and other traditionally permitted activities such as the collection of dry wood for fuel, flowers for home worship, and plant parts for medicinal use, are all forbidden as is swimming in the lake, a pleasure once enjoyed by local youth (Nagendra 2016b).

A notable state led example was the experiment with privatization of lakes in the year 2004-the state, considering itself unable to manage its lakes, began to lease them 
out to private entities. These organizations were allowed to commercialize activities on the lake. "Restoration" of such lakes, a term used by the municipality (Lakes Department) and the Indian government (NITI AYOG 2015) have involved the creation of landscaped parks, water fountains, boating and water sports, cafes, eateries, and night lights, along with a levy of entry charges. In reality these were not restoration projects from an ecological point of view, but can be characterized as lake revival projects. These privatized lakes supported a lesser diversity of socialecological uses as compared to their neighbouring public counterparts (Unnikrishnan et al. 2015). Livelihood based activities were almost entirely missing from privatized lakes, except in those circumstances where users made alternative arrangements for entry, using gaps in fences and the like to enter and use the water body.

Enclosing water commons by means of fences is not an activity restricted to state or privatized attempts at lake revival. In recent years, Bangalore has seen the rise of several community collectives who have worked in collaboration with local bureaucracies to restore and rejuvenate its lakes. In most of these cases, the effort is focused on increasing aesthetic and recreational value for urban middle-class residents (Unnikrishnan 2018). Accordingly, such lakes are fenced off, restrictions imposed on when the lake may be accessed and for what purposes it may be used for. Not surprisingly, these restrictions tend to keep out the most vulnerable populations such as livestock owners, urban foragers, and commercial washer-folk ("dhobies"). Local communities who used to depend on the water body now feel alienated and no longer consider themselves a part of the 'community' surrounding the lake. According to one of them,

We have lost not only the lake but the soil! We miss the soil! Do you know how the soil heals your body? You have to walk barefoot for that. You all are urbanized people, so you won't believe!

In Sowle Kere Lake, grazers from the nearby villages describe restrictions in access to the lake after the lake rejuvenation was completed. One of them, who owns six cattle, talks of how the lake was earlier managed by communities from local villages. He mentioned how communities like grazers could be ideal stewards-staying in the lake area in the day allows keeping a close eye on the lake. They can alert if a fire breaks out within the lake boundaries, clean the lake of its outgrowth while collecting fodder, check if sewage is coming inside the lake, check if the water color or quality changes, and collect reeds to keep the lake clean. Grazing also provides free manure for the lake. However, there are now multiple attempts to ban grazing. The municipality stated that cattle would destroy the fences and eat the plants. In the words of one of our interviewees, an 80 -year-old female cattle owner,
They have put a big fence around the lake. Do you know why? To keep people like us out. We don't look like you people, we don't dress like you all. They don't like us because of that. We come in dirty, torn clothes to cut some grass to feed our cows, but that big fence keeps us out. Why should we care about the lake when they don't want us there? We have our lives; we are happy with it.

Only contract fishing is now permitted by the Department of Minor Irrigations, a local nodal agency. However, traditionally, local fishers played an integral role in maintaining the lake. While fishing, they de-weeded the lake and during the monsoon, they blocked the sewage inlets manually to prevent wastewater inflow. Since they practiced traditional fishing, they used nets which caught bigger fish, leaving smaller fish to breed. While they fished, they also removed the non-biodegradable wastes like plastics from the lake during and after the monsoon. Overall, they managed the quality of the water of the lake since they were dependent on fishing. They also kept a watch on changes in water color/quality and helped in management of the lake.

Restorative activities around these lakes have however not paid attention to these lived cultural and social connections that communities have built around the lake system. At the same time, since many of these pre-existing socio cultural systems of water governance have been deeply iniquitous, changes in the way urban commons have been managed following lake rejuvenation have had some liberating effect, freeing many residents from oppressive gender and caste-based restrictions by virtue of their influence on people's livelihoods and lifestyles (Sen and Nagendra 2020b). An elderly Muslim woman who has lived in Bellandur village since she got married said that she has been living here for 65 years since it was a large agricultural village nourished by the largest lake in Bengaluru, the Bellandur Lake. They had their own agricultural land where they grew flowers, millets, paddy, and vegetables. The lake water was so clean that it could be consumed and was also used for household purposes like washing clothes and bathing cows. Lakes were used to irrigate adjacent agricultural fields. They have now stopped farming since the lake became polluted with sewage and industrial runoff. In last six years, she and her family earn income from renting their land to two small restaurants. She talks about the breakdown of social discriminations between communities, with Bellandur transforming into a high-end urban neighborhood.

We were otherwise close. But certain discriminations were explicit. High caste Hindus would send us a lot of food during the time of their festivals. But they never ate our food. It was only some of the lower castes, whose work was disposal of corpses and other menial jobs in the village, who would eat food from us. Now that Bellandur has 
changed, such things have reduced. People are now more open-minded.

She feels that caste discrimination has decreased after their neighbourhood transformed into a high-end urban area, with an upgraded road network, shopping centres, offices and malls. The money acquired by the rent or sale of land has liberated a lot of lower caste groups from previous oppression.

Another farmer also from Bellandur village said that during the local New Year festival of "Ugadi", village fairs and theatre plays were held where people from other villages came and participated in large numbers; but caste restrictions prevailed. His community was not permitted to drink water in a high caste household, or enter into temples. He feels that the urbanization of Bengaluru has facilitated the upward mobility of oppressed castes. Personally, he is content with Bengaluru becoming urbanized. As he mentions, there are now shops; all household items are now very easily available. Everyone has a good house to stay. People had to sell their farmlands to real estate developers, but that has made them better off than what they were before. Although he mentions that there were plenty of green cover in the villages earlier and the water and air were clean, he feels that life is comfortable now.

Previously we had to go to the city market to get anything like clothes or even some daily items. But now everything is available right here, as you can see.

A woman from Kaikondrahalli village, an agricultural laborer from an oppressed caste group, said,

Definitely our village looks good now, good to see beautiful tall houses and bungalows. Earlier we had agricultural fields in the spaces where now there are these houses. It's strange! Someone grows the food and someone else eats it. Earlier we used to eat the food that we grew. People now come from elsewhere and live here in our village. But it's good. There are good schools now, there is a lot of development: there are huge shopping malls. Now there are big buildings, which protects residents from rains and flood. Before one had to go to Delhi and Hyderabad (bigger cities) to see such buildings, but now they are here only-in our own village. It's good.

\section{Conclusions: Challenges Ahead}

Urbanization has often been linked to threats of dislodging lower-income settlements of marginalized communities, leading to multiple forms of exclusion (Jaitman 2015). However, some of the observations from the long-settled native communities of Bengaluru reveal other perspectives. Different caste groups who inhabited the erstwhile lake landscapes of the city speak about experiences of urban transformations in different ways. For the lower caste groups, urbanization has primarily afforded emancipation from rigid caste-based hierarchies and the associated ritualistic practices of purity, pollution, and social exclusion. The situated cultural norms and social structure, as most of them point out, were not communal and egalitarian, but characterized by deeply entrenched exploitations and inequity. Much of the pre-modern social technologies as well, as pointed out by Shah (2012: 525), strongly implied the "reproduction of cultural politics and power relations". Many of the narratives from grazers, fishers and agriculturalists who now have fixed incomes from jobs in organized sectors in the city and who live in affluent neighbourhoods, taken comprehensively, allow little scope to frame any linear critique of urbanization within these communities.

However, there is no denying that the overall process of lake revival in Bengaluru has largely followed ideas of gentrification, leading to an emphasis on recreational and aesthetic uses of lakes, while specifically excluding uses such as grazing, fishing, swimming and the collection of plant material that was largely conducted by marginalized communities who resided around these lakes. While some agriculturalists who owned land have profited from renting or selling their land, it is also likely that landless families may have lost access to resources and been forced to leave. We captured one account of those working as bonded labor around Sampangi kere who were especially affected, being severely and unjustly treated both before, and after lake revival. However, because our oral history narratives are restricted to those families that continue to live around these lakes, we do not have information on how widespread this effect would have been.

This trend of gentrification that we have described both historically and in the present day within Bengaluru is not unique to this city alone. Several peri-urban commons in and around India, especially in cities such as Gurgaon, Hyderabad, and Delhi (Vij and Narain 2016) have also followed similar trajectories. Indeed, the trend of dissociating local populations from local water infrastructures is characteristic of urban development trajectories found in other European cities such as Lyons, Munich, and Brussels (Winiwarter et al. 2016). This form of urban development has several problems. Gentrification, and enclosures of urban commons can potentially reduce pollution and increase aesthetic and recreational value. On the other hand, this form of governance greatly reduces the capacity of lakes to provide provisioning and cultural ecosystem services, as urban commons now become accessible only to a particular group of people, who tend to view the resource through similarly myopic visions.

There are some lakes however, that have experimented with ways of being more inclusive. For example, the revival of Kaikondrahalli lake in south Bangalore and Jakkur lake in north Bangalore have both been undertaken with 
active participation from multiple community groups. While aesthetic and recreational benefits are prioritised (through activities such as a community stage for cultural performances and the development of walking and jogging tracks), these lakes have also experimented with ideas like having a community garden managed by local women, engaging nearby Government schools for low-income children in lake management and nature education, and facilitating grazers to enter and cut grass to take back to their cattle. Workshops involving local bureaucrats and stakeholders in ways that facilitate dialogue between them and bring to the fore hitherto unheard voices, especially before planning activities relating to urban water commons, have not been done but might be another way to facilitate this process. In particular, such workshops need to be conducted in conjunction with ecologists to develop a deeper understanding of what ecological restoration means in practice, beyond the rhetoric used in planning documents.

In Bangalore, as with several other cities across the globe, the social justice aspect of these activities are less salient than the focus on aesthetics and recreation. Conflicts therefore are bound to arise between different competing visions of what urban redevelopment means, and the political leverage that certain members of the community wield over others. What needs to be recognized and acknowledged however, is the inherent heterogeneity, vulnerability, and historically produced inequity in urban planning processes and discourses. Plans, project proposals, and designs restored for lakes cannot be built upon the visions and imaginations of a select few: they must be designed through a dialogic process where a range of uses, and users, of these lakes can be accommodated. Conflict mitigation strategies therefore need to focus on optimal solutions that work across the heterogeneities existing within communities, while yet preserving and enhancing the quality and diversity of ecosystem services obtained from the urban commons. Only with that engagement can we envision a just future where cities look beyond greening and urban design towards societally relevant, ecologically embedded restoration, with the goal of improving ecological and social wellbeing for a larger set of urban citizens.

\section{Acknowledgments}

The authors are thankful to Azim Premji University for funding this research. The authors thank Enakshi Bhar for help with the map. Hita Unnikrishnan thanks the British Academy for a Newton International Fellowship awarded to her that additionally enabled this research. Funding for open access was provided by the CGIAR Research Programs on Forests, Trees and Agroforestry; Water, Land and Ecosystems; and Policies, Institutions, and Markets.

\section{References}

Annaswamy, T.V. 2003. Bengaluru to Bangalore: Urban History of Bangalore from the Pre-Historic Period to the End of the 18th Century. Bangalore, India: Vengadam Publishers.

Appadurai, A. 2001. Deep democracy: Urban governmentality and the horizon of politics. Environment and Urbanization 13:23-43.

Baviskar, A. 2018. City limits: Looking for environment and justice in the urban context. Pages 85-97 in S. Lele, S. Brondizio, J. Byrne, G.M. Mace and J. Martinez-Alier (eds.) Rethinking Environmentalism: Linking Justice, Sustainability and Diversity Cambridge, MA: MIT Press.

Benjamin, S. 2000. Governance, economic settings and poverty in Bangalore. Environment and Urbanization 12:35-56.

C. Broto, V. 2019. Urban energy landscapes. Cambridge, UK: Cambridge University Press.

Clarkson, B.D. and C.L. Kirby. 2016. Ecological restoration in urban environments in New Zealand. Ecological Management and Restoration 17:180-190.

de Certeau, M. 1984. The Practice of Everyday Life. London, UK: University of California Press.

Denis, E. and M.H. Zérah (eds). 2017. Subaltern Urbanization in India: An Introduction to the Dynamics of Ordinary Towns. New Delhi, India: Springer.

D'Souza, R. and H. Nagendra. 2011. Change in public commons as a consequence of urbanization: The Agara Lake in Bangalore, India. Environmental Management 47:84-850.

Elmqvist, T., H. Setälä, S.N. Handel, S. van der Ploeg, J. Aronson, J.N. Blignaut, E. Gómez-Baggethun, D.J. Nowak, J. Kronenberg, R. de Groot. 2015. Benefits of restoring ecosystem services in urban areas. Current Opinions in Environmental Sustainability 14:101-108.

Fox, H. and G. Cundill. 2018. Towards increased communityengaged ecological restoration: A review of current practice and future directions. Ecological Restoration 36:208-218.

Gibas, P. and I. Boumova. 2019. The urbanization of nature in a (post)socialist metropolis: An urban political ecology of allotment gardening. International Journal of Urban and Regional Research 44:18-37.

Gobster, P.H. 2007. Urban park restoration and the 'museumification' of nature. Nature and Culture 2:95-114.

Gurakkal, R. 1986. Aspects of reservoir system of irrigation in the early Pandya state. Studies in History 2:155-164.

Jaitman, L. 2015. Urban infrastructure in Latin America and the Caribbean: Public policy priorities. Latin American Economic Review 24:1-57.

Jaysawal, N. and S. Saha. 2014. Urbanization in India: An impact assessment. International Journal of Applied Sociology 4:60-65.

Johnson, L.R. and S.N. Handel. 2019. Management intensity steers the long term fate of ecological restoration in urban woodlands. Urban Forestry and Urban Greening 41:85-92.

Kaika, M. 2005. City of Flows: Modernity, Nature, and the City. London, UK: Psychology Press.

McDonald T, G.D. Gann, J. Jonson and K.W. Dixon. 2016. International standards for the practice of ecological restorationincluding principles and key concepts. Society for Ecological Restoration, Washington, D.C.

Melosi, M. 2008. The Sanitary City: Environmental Services in Urban America from Colonial Times to the Present (abridged edition). Pittsburg, PA: University of Pittsburg Press.

Mosse, D. 1997. The symbolic making of a common property resource: History, ecology and locality in a tank irrigated landscape in south India. Development and Change 28:467-504. 
Mundoli, S,. B. Manjunath and H. Nagendra. 2015. Effects of urbanisation on the use of lakes as commons in the peri-urban interface of Bengaluru, India. International Journal of Urban Sustainable Development 7:89-108.

Nagendra, H. 2016a. Restoration of the Kaikondrahalli Lake in Bangalore: Forging a new urban commons. Pune, Maharashtra: Kalpavriksh.

Nagendra, H. 2016b. Nature in the City: Bengaluru in the Past, Present, and Future. New Delhi, India: Oxford University Press.

NITI AYOG. 2015. Lake Restoration: Two successful models of lake restoration in Rajasthan (Mansagar) and Karnataka (Kaikondrahalli). niti.gov.in/writereaddata/files/bestpractices/Lake\%20 Restoration $\% 20$ Two $\% 20$ successful $\% 20$ models $\% 20$ of $\% 20$ lake\%20restoration\%20in\%20Rajasthan\%20\%28Mansagar\%29 \%20and\%20Karnataka\%20\%28Kaikondrahalli\%29.pdf.

Rao, M.S.A. 1970. Urbanization and Social Change: A Study of a Rural Community on a Metropolitan Fringe. Poona, India: Orient Longmans Ltd.

Rice, B.L. 1897. Mysore: A Gazetteer Compiled for Government, revised edition. London, UK: Archibald Constable and Company.

Sassen, S. 2000. Spatialities and temporalities of the global: Elements for a theorization. Public Culture 12:215-232.

Sen, A. and H. Nagendra. 2020a. The role of environmental placemaking in shaping contemporary environmentalism and understanding land change. Journal of Land Use Science 14:410-424.

Sen, A. and H. Nagendra. 2020b. The differentiated impacts of urbanization on lake communities in Bengaluru, India. International Journal of Urban Sustainable Development. doi:10.1080/19463138.2020.1770260.

Shah, E. 2003. Social Designs: Tank Irrigation Technology and Agrarian Transformation in Karnataka, South India. Hyderabad, India: Orient Longmans Ltd.

Shah, E. 2012. Seeing like a subaltern: Historical ethnography of premodern and modern tank irrigation technology in Karnataka, India. Water Alternatives 5:507-538.

Srinivas, S. 2002. Cities of the past and cities of the future: Theorizing the Indian metropolis of Bangalore. Pages 247-277 in J. Eade and C. Mele (eds.) Understanding the City: Contemporary and Future Perspectives. Oxford, UK: Blackwell.

Sudhira, H.S. and H. Nagendra. 2013. Local assessment of Bangalore: Greying and greening in Bangalore-impacts of urbanization on ecosystems, ecosystem services and biodiversity. Pages 75-92 in T. Elmqvist, M. Fragkias, J. Goodness, B. Guneralp, P.J. Marcotullio and R.I. McDonald (eds.) Urbanization, Biodiversity and Ecosystem Services: Challenges and Opportunities. New York and London: Springer.

Sudhira, H.S., T.V. Ramachandra and M.H.B. Subrahmanya. 2007. Bangalore. Cities 24:379-332.

Thippaiah, P. 2009. Vanishing lakes: A study of Bangalore city. Social and Economic Change Monograph No 17. Bengaluru, India: Institute for Social and Economic Change.
Unnikrishnan, H. 2018. Thinking beyond fairy lights and fountains: Lessons from the waterscape of Bengaluru. Ecology, Economy and Society - The INSEE Journal 1:95-99.

Unnikrishnan, H., B. Manjunatha and H. Nagendra. 2016. Contested urban commons: Mapping the transition of a lake to a sports stadium in Bangalore. International Journal of the Commons 10:265-293.

Unnikrishnan, H. and H. Nagendra, H. 2018. From pulley to pipe: The decline of the wells of Bangalore Arcadia (Spring 2018). Rachel Carson Center for Environment and Society.

Unnikrishnan, H. and H. Nagendra. 2020. Quenching a city's thirst: The shifting waters of Bangalore. Elsevier Reference Module in Earth Systems and Environmental Sciences doi.org/10.1016/ B978-0-12-409548-9.12425-X.

Unnikrishnan, H., B. Manjunatha, H. Nagendra and V. Castán Broto. 2020. Water governance and the colonial urban project: The Dharmambudhi lake in Bengaluru, India. Urban Geography. doi:10.1080/02723638.2019.1709756.

Unnikrishnan, H. and H. Nagendra, H. 2015. Privatizing the commons: Impact on ecosystem services in Bangalore's lakes. Urban Ecosystems 18:613-632.

Unnikrishnan, H., S. Sen and H. Nagendra. 2017. Traditional water bodies and urban resilience: A historical perspective from Bengaluru, India. Water History 9:453-457.

Vij, S. and V. Narain. 2016. Land, water, and power: The demise of common property resources in periurban Gurgaon. Land Use Policy 50:59-66.

Winiwarter, V., G. Haidvogel, S. Hohensinner, F. Hauer and M. Bürkner. 2016. The long term evolution of urban waters and their nineteenth century transformation in European cities. A comparative environmental history. Water History 8:209-233.

Wirth, L. 1938. Urbanism as a way of life. American Journal of Sociology 44:1-24.

Amrita Sen (corresponding author) Department of Humanities and Social Sciences, Indian Institute of Technology Kharagpur, West Bengal 721302, India, and Visiting Faculty, Azim Premji University, Bengaluru, Karnataka, amrita@apu.edu.in.

Hita Unnikrishnan, Urban Institute, The University of Sheffield and Visiting Faculty, Azim Premji University, School of Development, Bengaluru, Karnataka, India.

Harini Nagendra, Professor of Sustainability, School of Development, Azim Premji University, Bengaluru, Karnataka, India. 